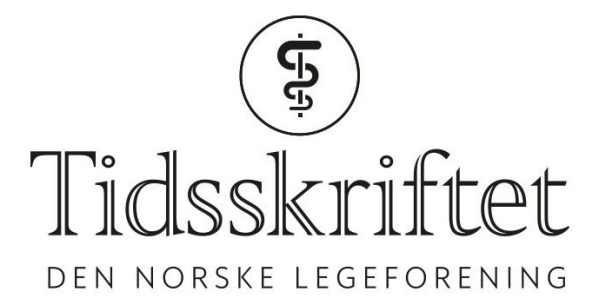

\title{
Identitetens sykdom og sykdommens identitet
}

KOMMENTAR

\section{BJØRN HOFMANN}

E-post: bjoern.hofmann@ntnu.no Bjørn Hofmann er professor ved Norges teknisk-naturvitenskapelige universitet. Ingen oppgitte interessekonflikter.

I en velskrevet og informativ leder gir Anne Kveim Lie og Ketil Slagstad en fin oversikt over hvordan kjønnsidentitet har vært klassifisert som sykdom gjennom tidene (1). Dette er viktig, da kjønnsidentitet har voldt store plager for enkeltmennesker - både i og utenfor helsevesenet.

Samtidig reiser sykdomsklassifiseringer og diagnosesystemer grunnleggende spørsmål om hva som er sykdom. Lie og Slagstad viser på en glimrende måte diagnosenes dobbelthet: De gir rettigheter og tilgang til ønsket behandling, samtidig som de kan stigmatisere. Fordi man ønsker tilgang på kjønnsbekreftende behandling, har aktivister og fagfolk arbeidet frem kjønnsinkongruens som en sykdom i ICD-11.

Lie og Slagstad støtter denne utviklingen. Men de berører ikke det viktige og vanskelige spørsmålet om hva det er ved kjønn (og identitet) som gjør at vi mener at helsevesenet bør etterkomme våre ønsker og behov?

Jeg kan ha mange ønsker og behov knyttet til min selvoppfatning og identitet. Jeg kunne for eksempel plages av at min fysiske høyde ikke tilsvarte min identitet («høydeinkongruens»). Eller jeg kan oppfatte meg som asiat eller som hårete, selv om mitt ytre ikke bekrefter dette. Begge er sterke identitetsbekreftende trekk. Hva er det ved kjønnsidentiteten som gjør at den trumfer andre identitetstrekk, som jeg måtte ønske å endre? Hvis jeg kan få «resept på en parykk ... hormonbehandling ... og kirurgi» for kjønnsinkongruens, hvorfor kan jeg ikke få det samme for andre identitetsrelaterte inkongruenser?

Et annet vanskelig spørsmål, som Lie og Slagstad ikke berører, er hvorvidt vi kunne unngå eller redusere diagnosenes stigmatiserende effekt ved å gjøre tilgang til helsetjenester uavhengig av diagnoser. Det å gjøre tilgangen til helsetjenester diagnoseavhengig, politiserer diagnosene. Med et helsevesen som i stadig større utstrekning tar seg av forhold og fenomener som ikke er relatert til sykdom, slik som svangerskap, så burde man kunne løsrive tjenestene fra diagnoser. Jeg mener ikke at dette er svaret, men at spørsmålet er viktig.

I tillegg til kjønnsidentitetens eksepsjonalisme og diagnosenes politisering, kan det synes som et paradoks at i individualismens tid, så forlanger vi at fellesskapet står ansvarlig for formingen av vår individuelle identitet. Samtidig biologiserer vi kjønn. Paradoksene står i 
kø når «kulturen griper til kniven».

LITTERATUR:

1. Lie AK, Slagstad K. Diagnosens makt. Tidsskr Nor Legeforen 2018; 138. doi: 10.4045/tidsskr.18.0438. [CrossRef]

Publisert: 20. august 2018. Tidsskr Nor Legeforen. DOI: 10.4045/tidsskr.18.0548

(C) Tidsskrift for Den norske legeforening 2020. Lastet ned fra tidsskriftet.no 